\title{
An Overview of the Development of STPs in Indonesia
}

\author{
Sinta Ningrum, Nunung Runiawati \\ sinta.ningrum@unpad.ac.id ${ }^{1}$, n.runiawati@unpad.ac.id ${ }^{2}$ \\ Public Administration Department, Universitas Padjadjaran, Indonesia
}

\begin{abstract}
The background of this research is the development of Science and Techno Parks (STPs) in Indonesia, which has obtained special attention from the government since 2015. It is hoped that the establishment of STPs will increase the people's productivity and competitiveness in the international market so that the people of Indonesia are able to advance and awake together with other Asian nations. The purpose of this study is to identify problems and challenges faced by STPs in Indonesia after four years of receiving special treatment from the government. This is intended as evaluation materials for government policy on the development of STPs. Meanwhile, the recommendation of the research is to identify the need for the institutional development of science and techno parks in the future. This research used qualitative research methods. The results showed that there were a number of problems both in terms of input and process. Meanwile, the challenges in the future comprise the need for the improvement of cooperation among the parties, integration of various regulations, and the improvement of commitment among them.
\end{abstract}

Keywords: Commercialization, Development, Science and Techno Park, Transfer Technology Office.

\section{Introduction}

There is a trend all over the world in which governments encourage the creation of spin-off companies to increase the economic growth in the era 4.0. Callan proposes that the economic growth strategy by creating new companies is considered to be more effective if it is conducted by the government because besides creating jobs, the founding of spin-off companies has intangible benefits, such as the improvement of organizational image, attracting dynamic, forming entrepreneurial spirit among students and researchers, enriching the quality of research and establishing better relations with industries[1].

In Indonesia, the establishment and development of STPs are led by the Ministry of Research, Technology and Higher Education. The development of STPs is part of President Jokowi's vision and mission which is specified in the sixth point of the Nawacita, "increasing the people's productivity and competitiveness in the international market so that the people of Indonesia are able to advance and awake together with other Asian nations" [2]. To implement this policy during the period of the 2014-2019 National Medium-Term Development Plan (RPJMN) the government has planned to develop 100 STPs all over Indonesia. The government has planned to establish 13 new industrial areas outside Java Island in 2015, such as in Papua, North Kalimantan, Jambi, and Bengkulu and to make Bandung Techno Park (BTP) a role model for the establishment of 100 STPs all over Nusantara. The development of sciences and techno parks in some regions of Indonesia emphasizes the integration of universities, local governments, and industries so that innovation increases and is able to compete at the world level [3]. 
From institutional perspective, an STP is an organization managed by professionals whose main aim is to increase the wealth of its community by promoting the culture of innovation and the competitiveness of its associated businesses and knowledge-based institutions [4]. Its main objective is to increase the economic growth and to strengthen the role of knowledge and technology in the economic development by promoting the culture of innovation and related business competitiveness, and also knowledge-based institutions [5]. Felsenstein proposed two functions of STPs. The first function is to be a nursery and a region that protect technology and play a role as an incubator, to protect and to develop technologybased startup companies, and to facilitate technology transfer between research centers/universities and companies located there (tenants), to encourage the emergence of spin-offs from researches conducted by universities, and to stimulate the emergence of innovative products and process. The second goal or function is to be a catalyst for the economic development in a region (regional economic development) and to revitalize the economy of a region [6].

Currently, STPs need institutional reinforcement, considering the existence of the Transfer Technology Office (TTO). TTOs act as a bridge between universities and market environment. Some of its functions are to protect university proprietary rights in order to generate returns, to support pre-commercialization of inventions, and to support local or regional economic development [7].

The purpose of this research is to analyze problems and challenges faced by STPs, whether they are managed by the central government, local governments, universities, and private companies four years after the imposition of the policy on the development of STPs. Meanwhile, the recommendation of the research is to identify the need for the institutional development of science and techno parks in the future.

\section{Methodology}

This research used qualitative research methods with the historical-comparative study approach to analyze various current issues of the problems related to science and techno parks developed by the central government, local governments, universities, and private businesses.

Data collection techniques were conducted through interviews and literature review. The informants in this research were stakeholders related to science and techno parks, i.e. organizers of STPs from universities, local governments, and private sectors and some agencies involved in the management of STPs in Indonesia. Therefore, overall there were 21 STPs studied, five of them through interviews and the rest by analyzing performance documents of the STPs. Meanwhile, based on the management unit, the configuration of the studied STPs was as follows: $48 \%$ of them were from universities; $38 \%$ of them were from local governments; $9 \%$ of them were from the central government; and $5 \%$ of them were from private parties. The information digging which was carried out through interviews and performance documents of STPs comprised the performance achievement of STPs to the present time, the problems they were facing, and the working plan.

The next stage was data analysis. To find out the problem in the management of STPs, the data collected through interviews and literature studies were grouped based on the emerging main issues, such as the problems of human resources, finance, input/material, procedure, marketing, and institutional problems.

To see the mapping of the needs for the development of STPs, a gap analysis was conducted between the implementation of STPs and five levels of analysis which are able to affect the organizational capacity as proposed by Grindle \& Hilderbrand [8]. 


\section{Findings}

The establishment of STPs has become one of the programs to reduce unemployment in Indonesia by providing training and education for citizens of productive age. Besides that, it is hoped that the establishment of 100 techno parks will support the existing industrial areas. The concept of STP according to the Ministry of Research, Technology and Higher Education is defined as an integrated area combining industries, universities, research and training centers, entrepreneurship, banking, central and local governments in a location which enables more efficient and faster current of information and technology [5].

Some universities, like IPB, have initiated programs similar to the STP since twenty years ago but the government's commitment relating to the development of STPs has started to be conducted intensively just since the era of President Joko Widodo (in 2015) [5]. The government has planned to develop 100 centers of STPs or known as techno parks for industries (during the period of the 2014-2019 RPJMN) all over the regions in Indonesia as stated in the government's program of Nawacita [5]. The establishment of techno parks has become one of the programs for reducing unemployment in Indonesia by providing training and education for citizens of productive age.

3.1. Problems in the Development of STPs

The development of science and techno parks in some regions of Indonesia emphasizes the integration of universities, local governments, and industries so that innovation increases and is able to compete at the world level. However, the effort to realize technological commercialization of the establishment of STPs is relatively new in Indonesia, therefore as a newly formed institution they still find some problems in the operation (especially those related to input and process in implementing the policy on STPs). Based on the result of interviews, some problems emerging in the operation of STPs as follows:

a. The Problem of Human Resources

The problem of human resources in STPs is related to those of the organizers of STPs and partners of STPs, such as researchers/inventors/tenants. The problem of human resources of the organizers of STPs is related to their quantity and quality which have not met the requirements of the development of STPs. In STPs of universities, the organizers are generally active lecturers who have had the obligation to conduct the task of Tri Dharma Perguruan Tinggi (Education, Research, and Community Service) and that is why the operation of the programs of STPs takes just part of their working time, hence they do not focus on the performance achievement of STPs.

Based on interviews with an organizer an STP of a local government, he stated that the employment status of the organizers of STPs of local governments is generally still at the level of echelon 3 or 4; therefore they find obstruction when they build an ecosystem with employees who have a higher employment status in other agencies. Besides that, the organizers of STPs of local governments need some times to learn the function and role of the new institution which has become their task. Almost all organizers of STPs studied in this research have not yet had personnel who have possessed certificates of business valuation and technology valuation. Other competencies required from the organizers of STPs are the valuation of research result, strategies for developing STPs and business incubation.

The problem of human resources in the management of STPs by the private parties like Nongsa Digital Park (NDP) could be overcome by cooperating with some parties, universities both in Indonesia and Singapore and also a Singapore-based, Glints, which has helped to increase the number of tenants of NDP in a period of six months to 71 tenants.

Related to the partners of STPs, the main problem frequently found by STPs, both at the levels of universities and local governments, is a shortage of researchers/inventors/tenants 
who have saleable products, which means besides the innovation products have a good quality, tenants have possessed all required permission so that they are allowed to be sold at the market. Therefore, it is necessary to improve the competencies of the partners of STPs to increase the product competitiveness at the market.

\section{b. The Problem of Budget}

Some budget-related problems faced by the organizers of STPs at the levels of universities and national/local governments are as follows:

1) Sufficiency: The lack of the operating budget for supporting the development of tenants, financing, and business development;

2) The pattern of financial management has not yet been clear;

3) Liquidity: Realization of Funds Disbursement of National Revenues and Expenditures Budget (APBN) just before the end of the year has made the performance has not yet been felt maximum;

4) Dependency on the budget from the government, that is as much as 80 percent, compared to the budget from private sectors.

c. The Problem of Materials

Some problems related to materials/raw materials faced by the organizers of STPs at the levels of universities and national/local governments are as follows:

1) Some STPs import raw materials due to a lack of domestic raw materials;

2) The availability of the raw materials of the product has not yet been guaranteed.

3) The STPs face a hindrance in obtaining innovative products, mainly in STPs of local governments. The input is still in the form of the basic invention which should go through a long process to be marketable. Besides that, there are very few of the results of research conducted by universities which have been ready to be commercialized.

d. The Problem of Procedure/Method

There has not yet any policy to encourage the downstream process of the results of research. Based on the document analysis result of informant 7, it is known that some STPs have not yet been supported by policies like the procedure for collecting service fees. In addition, some working units have not yet had research roadmap as informed by informant 10 . Moreover, informant 5 stated that the policy of research roadmap is not sufficient because it needs a policy that encourages the downstream process of the research.

e. The Problem of Marketing

The main problems associated with marketing are related to industries which have not yet entered STPs and some other problems, such as:

1) The lack of synergy among stakeholders to facilitate permission for commercialization of the result of the downstream process. It needs integration with the service of intellectual property and the existing incubation program;

2) There has not yet been the legality permission for the export and import of the products of the tenants;

3) The lack of marketing networks of the products;

4) Difficulties in finding investors;

5) There has not yet been any institution or expert with a certificate in technology/innovation valuation;

6) There has not yet been any market review related to the resulted products;

7) The product results of the tenants have not yet been completely absorbed by the market so that the tenants' revenues cannot be measured accurately;

8) There is a lack of public's awareness to use domestic products and the local products have to compete with relatively cheaper imported products. 
9) There is still a low rate of technology transfer to the users and the public.

The core business of NDP is co-working space. However, they are able to make use of their cooperation networks by cooperating with a Singapore-based startup so that they are able to increase the number of tenants that join with NDP in a period of six months. This condition has an impact in increasing the absorption of young Indonesian workforce to work at Singaporean companies that have their offices at co-working space of NDP.

f. The Problem of Facilities/Infrastructures

The problems found related to the lack of facilities and infrastructures, especially those faced by the organizers of STPs at the levels of universities and national/local governments, comprise:

1) The STPs have not yet had integrated laboratories for obtaining certificates of technology products;

2) Facilities and infrastructures for a standardized production process have not yet been available;

3) Facilities and infrastructures have been obsolete and need repairs;

4) There is a constraint on the distance of the offices of STPs which are far from the source of input, industries, and market.

g. Institutional Problems

Some institutional problems faced especially by the organizers of STPs at the levels of universities and national/local governments are:

1) Some STPs are charged with the responsibility for managing STP but they have not had definitive institutional form. It occurs in the working unit of informant 7. The implication is that some programs that have been approved cannot be conducted because the institution has not yet been ready;

2) There has not yet been any mutual commitment to the development of STP among the leaders of universities/institutions. It occurs in newly-formed STPs. The result of interviews with informant 10 indicates that the focus of the policy implementation of STPs is just to make an effort to establish an STP in their working unit but the leader has not yet had the platform for developing the STP. Besides that, based on information from informants 1 and 4, the lack of understanding from the leader related to the development of STPs and the frequent change of leadership have caused changes in the policy which eventually obstruct the development of STPs;

3) There has not yet been any institution in the form of a company for conducting commercialization. Informants 1 and 2 stated that in the STP managed by universities it is necessary to form a special unit in the form of a company to facilitate commercialization of the results of the downstream process;

4) There has not yet been any coordination with local governments to develop technology/results; facilitation of permission; and funding.

5) The development of STPs goes slowly because they are still in the learning process.

6) An ecosystem that enables STPs to function optimally has not yet been formed.

3.2. Challenges in the Development of STPs

The demand from the intermediate institution of STPs is that in the future it becomes a working unit that is able to conduct commercialization of technology. It is hoped that this institution is able to guarantee the results of research which have the potential to be utilized, both for science and commercial purposes. To face the existing problems, it is necessary to adopt a strategy that is able to identify the mapping of needs of the intermediate institution of STPs in the future. By using the approach of organizational capacity [8] the challenges it faces are as follows: 
a. The need for an ecosystem that enables the occurrence of penta-helix synergy;

b. The need for harmonization of regulation and the existence of a policy that supports the continuation of the program of STPs;

c. Extension of cooperation networks;

d. The improvement of commitment among stakeholders to facilitate commercialization of technology;

e. Being seen from the side of institutional context, there is a need for standardization and certification of the management system with ISO, support of funds, and business matching to attract investors;

f. Being seen from the side of task network, there is a need for coordination among the central government, local governments, and universities concerning the development of technology/products, permission facilitation, and funding in the scheme of a quadruple helix (a-b-c-g).

g. Being seen from the side of the organization, there is a need for gradually increasing facilities of tools and production rooms, more intensive supervision toward the leaders (policymakers) related to the development of STPs, the founding of enterprises in the scheme of STPs. Being seen from the side of human resources, there is a need for strengthening competencies and professionalism of human resources which can be conducted through the program of the development of human resources that focuses on the improvement of special competencies of the organizers of STPs.

Some of the challenges can be anticipated by optimizing the intermediate institution or known as the transfer technology office (TTO). Based on Government Regulation Number 20 Year 2005 it is stated that, "Technology transfer is the acquisition of the ability to make use of and to acquire knowledge and technology among institutions, agencies, or people, whether they are located in domestic area or they are from the abroad to domestic area in vice versa." Intermediate institutions basically act as a bridge for the products of innovation to be sold at the market. It is hoped that the TTO is able to function as a talent pool for identifying innovators who have the potential for commercialization because not all products of research that have the potential to be exploited in scientific or commercial purposes have commercial values. Based on the previous research there are some factors that affect the effectiveness of the TTO, among other things, the cultural environment of local communities [9], incentives in the activities of the transfer of knowledge and technology, learning skills [10] and cooperation [11].

\section{Conclusion}

Based on the result of the research the problems of STPs concerning the aspect of input, among other things, related to the problem of the availability and continuation of raw material of the products, innovative inventions, a shortage in the number and (certified) competencies of the organizers, the lack of investment, dependency on the budget from the central government (the Ministry of Research, Technology and Higher Education), the lack of facilities and infrastructures that meet the standard of National Agency of Drug and Food Control (BPOM).

Being seen from the side of process, the problems faced by STPs comprise the institutional problem, the management of the budget that has not yet been well performed, some STPs that have not yet had research roadmap, standard operating procedures (SOP), and a policy that encourages the downstream process of the research. The problems concerning marketing comprise the lack of synergy among stakeholders to facilitate permission for commercialization of the products of the downstream process, difficulties in finding investors 
and the lack of marketing networks, unavailability of mutual commitment to the development of STPs, unavailability of coordination among stakeholders which makes STPs run slowly.

Meanwhile, the challenges in the future comprise the need for the improvement of cooperation among the parties, integration of various regulations, and the improvement of commitment among them. Some of the challenges can be anticipated by optimizing the intermediate institution or known as the transfer technology office (TTO). In general, there are two main forms intermediate institutions. The first form is separated from the institution for knowledge development, in which it plays a role more as a technology broker to whom the institutions that provide knowledge give license to use the technology from the institution for knowledge development. The second form is the institution for knowledge development for the purpose of technology transfer which is often known as research spin-off.

The development of the form of STPs, whether they are managed by universities, the central government, or local governments, needs to adhere some principles as follows: 1) autonomous, in which they institutionally have the authority to regulate their own affairs and their own finance considering that the partnership relation of STPs is dynamic and it has a commercial purpose of increasing revenues in their regions; 2) professional, in which the organization of STPs is managed by the parties that have expertise in supporting the commercialization of the downstream process; 3 ) encouraging the growth of technology for acceleration; 4) encouraging the growth of technology-based startup companies and generating revenues from the commercialization result; and 5) able to give contribution to the regional economy.

\section{References}

[1] Callan, B. (2001). Generating Spin-offs: Evidence from Across the OEDC. STI Review Volume 2000 Issue 1: Special Issue on Fostering High-tech Spin-offs: A Publc Strategy for Innovation , 13-55.

[2] www.kpu.go.id

[3] https://nasional.sindonews.com/read/970755/149/pemerintah-akan-bangun-100-techno park1425268102

[4] International Association of Science Parks and Areas Innovation

[5] Kementerian Riset, t. d. (2015). Pedoman Pembangunan dan Pengembangan Taman Sains dan Teknologi. Jakarta: Kementerian Riset, teknologi dan Pendidikan Tinggi.

[6] Aldianto, L., Mirzanti, I. R., \& Desy Sushandoyo, E. F. (2018). Pengembangan Science dan Technopark Dalam Menghadapi Era Industri 4.0-Sebuah Studi Pustaka. Jurnal Manajemen Indonesia Vol 18 No.1, 68-76.

[7] Good, M., Knockaert, M., Soppe, B., \& Wright, M. (2018). The Technology Transfer Ecosystem in Academia. An Organizational Design Perspective. Technovation . https://doi.org/10/1016/j.technovation.2018.06.009

[8] Grindle, M. S., \& Hilderbrand, M. E. (1995). Building Sustainable Capacity in Public Sector: What Can Be Done? Public Administration and Development Vol 15, 441-463.

[9] Al-Thawwad, R. M. (2008). Technology Transfer and Sustainability - Adapting Factors: Culture, Physical Environment, and Geographical Location. Proceedings of The 2008 IAJCIJME International Conference .

[10] Gibson, G. V., \& Sung, T. K. (2000). Knowledge and Technology Transfer: Levels and Key Factors. Proceeding of the 4th International Conference on Technology Policy and Innovation .

[11] Gouza, A. (2006). Key Factors of Knowledege Transfer Within University Spinn-Offs. 